[Weir, K. (2001). Sexuality Education - The Values Education Debate Continues. New Zealand Annual Review of Education, 10, 109-123]

\section{Sexuality Education - The Values Education Debate Continues}

\section{KAMA WEIR}

\section{Abstract:}

Values education is a complex and contested area of curriculum in New Zealand schools. This article looks at the values education debate of the 1970s and 1980s and draws parallels with contemporary issues in values education, particularly sexuality education.

\section{"Let children be children"}

$\mathrm{T}$ he complex and contentious nature of values education was illustrated by recent experiences of teaching sexuality education to pre-service primary and secondary students. The comments of some graduate students enrolled in one of my health education classes of 2000 indicate the intensity of feelings associated with the topic of sexuality education: "Let children be children", "only parents should be teaching about sex" and "teaching about sex at school could corrupt children" (personal communication, November 21, 2000).

The complexity of values education was also revealed in an article

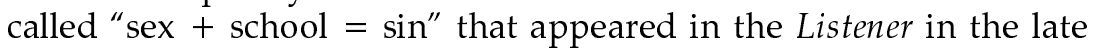
1990s. The article noted that Jenny Shipley, as Minister of Health, had been very supportive of the Family Planning Association teaching resource "Challenges and Change" when it was launched in 1994, although her subsequent promotion of values in schools had encouraged some Christian groups " to gear up their crusades attacking Family Planning. Their aim? To get 'immoral' material out of New Zealand schools" (Stirling, 1998, p. 30).

The controversial nature of sexuality education ${ }^{1}$ has been evident in recent media attention given to conflicting views on student access

\section{Kama Weir}

to condoms, sexuality education resources, and student virginity pledges.

\section{Parallels with An Earlier Debate}

The emergence of sexuality education as a contentious topic over the last few years has close parallels with the values education ${ }^{2}$ debate which took place in the 1970s and early 1980s. This debate was marked by high levels of emotion, evident at many levels. Individuals, school communities, educational and religious groups, politicians and bureaucrats all believed they had a stake in the issues, and were either passionate in their advocacy or at least acutely aware of the passions involved.

\section{Values Education Becomes An Issue in the 1970s}

The interest in values education in the 1970s occurred in the context of major social and economic change for New Zealand. Within New Zealand, significant developments such as the introduction of the contraceptive pill and changing patterns of employment were affecting economic and social relationships. Two pieces of legislation reflected changing times and were also themselves catalysts for further social change: the Domestic Purposes Benefit of 1973 provided economic means for women to survive as solo parents; and the Matrimonial Property Act of 1976 provided for a 50/50 division of family property regardless of financial contribution. This legislation and the consequent increase in government social expenditure were accompanied by a rise in media concern over solo mothers, divorce rates and changing attitudes to sexuality.

The social and economic changes of the time were closely linked. The growth of the feminist movement provides an example of the complex nature of the changes taking place. Feminist writers Anne Else and Rosslyn Noonan (National Secretary of the New Zealand Educational Institute 1988-1996) wrote:

Feminists didn't come out of nowhere, nor did we emerge simply in reaction to what we suddenly perceived to be the evils of an unchanging status quo. Deep changes were already occurring in areas as apparently unconnected as the export market and family patterns. (Else \& Noonan, 1993, p. 193)

The promotion of values education was one of the responses to the changing environment. Feminist organisations were among the groups that focussed on sexuality education, the most controversial element of 
values education. National organisations such as the Family Planning Association, the Marriage Guidance Council and the Department of Health also tried to get the Department of Education to make a commitment to sexuality education.

Not everyone was comfortable with the possibility of changes in classroom teaching. One example from this time was a letter written to the Department of Education in April 1973 by J. M. Amies, Head of Department of Social Studies at Buller High School. The writer's major concern was that the Department was indicating a move away from the teaching of "basic values". Amies was particularly concerned that the "moral habits listed in the 1929 syllabus" had disappeared from a series of discussion papers on the secondary school curriculum that were published by the Department of Education in 1972: "apart from a vague reference to'Social Justice' no such aims appear in the present proposals and, instead, a great deal is made of the fact that traditional values are often questioned today."

Amies argued that although some values might change, basic values like those referred to in the 1929 syllabus did not:

There could be nothing worse than an indecisive or uncertain attitude to the basic moral virtues referred to in the 1929 syllabus. To assume that these values may change is to assume that society will destroy itself. (Amies to the Department of Education, April 30,1973)

He went on to express concern about the Health Education handbook (Department of Education, 1969) that he saw as showing an indecisive attitude to "moral questions":

Drugs are to be discussed but they are not condemned, and when promiscuity, prostitution and homosexuality are discussed, the teacher may present various viewpoints but there should be no effort to morally judge these. (1973)

The Department of Education and "Values Education"” - The Ross Report The viewpoint of the teacher from Buller was not an isolated one. Many individuals and groups at this time believed that sexuality education was the prerogative of parents, and called for a return to basic values. Other voices urged schools to take on sexuality education. The Department of Education was caught in the middle. In response to these pressures, the Director General of Education, W. L. Renwick set up a committee in March 1973 with the task of producing a discussion paper "on the issues involved in developing programmes in human development and relationships in schools" (Renwick, foreword to Human Development and Relationships in the School Curriculum, 1973). The purpose of the discussion paper was to stimulate debate - it certainly achieved this aim. Better known as the Ross Report, after its chairman, Jim Ross, the discussion paper became the catalyst for the vigorous promotion of widely differing view points on human development and relationships.

\section{The Media Contributes to the Debate}

The role of the media in cultivating, and to some extent shaping, the debate was evident when the Ross report was released. The viewpoints aired by the media were not surprisingly those that were the most critical of the report. The New Zealand Herald printed the transcript of a speech given by the morals campaigner Patricia Bartlett ${ }^{3}$ under the headline: "Booklet prepared as hastily as a shotgun marriage." Bartlett's speech had been delivered to "almost 200 people at Arahanga Intermediate School in November of 1974." The Herald's introduction described the Ross Report as "a booklet which had found intense opposition in New Zealand's crusader for continence, Patricia Bartlett." Bartlett used the comments of Professor Bonham of Auckland University (and National Women's Hospital) as the starting point for her criticism. According to Bartlett, Bonham made a statement on television that the discussion paper was "brilliant and that a certain frustrated individual was criticising it." (Bartlett assumed, probably correctly, that the individual referred to was herself).

The acrimonious and personal nature of the debate revealed again the intensity of feelings about sex education; later in the speech Bartlett claimed Professor Bonham's views constituted a "pagan philosophy of no self control before marriage."

\section{The Department of Education and "Values Education" - The Johnson Report}

Politicians and bureaucrats were very aware of the strength of feeling involved in values education discussions. The next major Education Department initiative was the establishment of the Committee on Health and Social Education, the group which in 1977 produced Growing Sharing, Learning. (The report is usually referred to as the Johnson Report after its chairman, J. G. Johnson.) This report was the most extensive and significant of the series of reports produced during the $1970 s^{4}$ and spanned two governments and three ministers of 
education. It is notable for the immense investment of time involved in its production and subsequent debate, and for the heat generated during the process. At the end of it all, the work of the committee resulted in some new directions for schools in such areas as guidance, special needs and outdoor education. This was not the case for values education which was a fiercely contested area, with sexuality education attracting the most attention.

The focus on sexuality education displeased the Minister of Education, the Hon M. (Merv) Wellington. In an address to the Auckland Federation of Parent Teachers' Associations, the Minister was clearly unhappy that sex education had once again dominated discussion. He emphasised the non-controversial content of the Johnson Report (1977) and complained that debate on this Report was "too hung up on the controversial sex education clause" (New Zealand Herald, undated reference in Department of Education files).

\section{Pressure Groups and Values Education}

The Concerned Parents' Association was one of the more prominent pressure groups opposed to sexuality education in schools. Another like-minded group was formed in 1979 when the Society for the Protection of the Unborn Child (SPUC) joined the Family Rights' Association to form the Council of Organisations for Moral Education with the unfortunate acronym of COME. David Elliot-Hogg, a former inspector with the Department of Education was appointed Council secretary. The Family Planning Association (FPA) was very fearful of the possible effects of COME. Alongside a newspaper clipping reporting the formation of COME, notes from FPA records indicated their belief that COME had its own agenda beyond opposing sexuality education:

COME is a now a powerful, politically sophisticated organisation which will use its influence with the Department of Education and with the political parties to impose its moral-religious code on to all New Zealanders in State schools regardless of the wishes of parents. Civilised acceptance of diversity in society quickly turns into bitter conflict if the state favours one belief over others. ( FPA, 1979)

A letter written in March of 1980 by Pat Stockley, secretary of the National Organisation for Women (NOW), to Jack Mulheron, Secretary of the Committee for the Defence of Secular Education, also expresses alarm at the activities of SPUC, CPA and The Society for the Protection of Community Standards:
My Committee has asked me to assure you of our wholehearted support for your organisation and the goals it intends to achieve. We are very conscious that SPUC, "Concerned Parents" and the "Society for the Promotion of Community Standards" - virtually the same people - will stop at nothing in their fanatical pursuit of sexual ignorance for all young people. As Dr Geiringer says, in "SPUC'em All", "it is important at all times to remember the fanaticism of the movement. SPUC is not an ordinary pressure group within a small democratic society. It is a powerful, international pressure group of irrational fanatics." (Stockley to Mulheron, March 20, 1980)

Conservative groups held similar views on the liberal groups; moral education was not an issue to be discussed dispassionately.

Sexuality Education - At The Centre of The Values Education Debate The values education debate which took place during the 1970s and 1980s was marked then by a focus on sexuality education and by the high level of emotion evident at many levels. Views on sexuality education reflected fundamental beliefs and apprehensions about family, schooling, teacher, student and parent rights and responsibilities, and even the shape of society. These views tended to polarise people's responses.

Despite the Department of Education's efforts to encourage debate in a broad context, public responses to the Ross Report had a narrower focus, being particularly concerned with sexuality education. An example of pressure group activity in the early 1970s illustrates this preoccupation. In 1974 the Christchurch group connected with the CPA sent out a collection of papers to school committees around New Zealand. The collection included a covering letter to each chairman expressing alarm over lack of opportunities for parents to share their opinions on the sex education programme (the Ross Report) which the CPA feared was about to be implemented, and concern at material being circulated by the New Zealand Council for Educational Research: ${ }^{5}$

It would appear that this material has been prepared and circulated on the assumption that the Department of Education will introduce the programme, regardless of any expression of parents' opinion. If we, as parents, do not now establish our rights over what our children are being taught and exposed to, we may lose these once and for all. 
Responses to the Johnson Report also focussed on the recommendations relating to human development and relationship education. The weekly tabloid New Zealand Truth, noted for its sensationalism and political conservatism, provided its readers with many comments on the Johnson Report. A typical headline of this period read "That Report's a Shocker" (New Zealand Truth, September 12, 1978).

Ironically, a consequence of these two features of the debate (the emotion and the concentration on sex education), was the wariness of both bureaucrats and politicians about making an unequivocal stand. The passionate and uncompromising nature of the views expressed by their constituents meant there was no apparent safe middle ground for the country's leaders. Media amplification of the debate intensified the issues and made politicians cautious about articulating a clear position. While it is clear from initiatives such as the Ross and Johnson Reports that the Department of Education was willing to advance discussion and promote action on values education, the strength of public reaction and conflicting interpretations of the outcome of these initiatives made it difficult for the Department to claim a clear mandate to proceed with curriculum development.

\section{Consultation, Now What?}

The decade which covered the Ross Report and the Johnson Report had been marked by new levels of consultation. At the end of the decade, consultation had revealed issues which remained unresolved. Consensus on values education was elusive because competing moral positions were evident and hence it seemed unlikely there would ever be an agreed national position. Despite this apparently discouraging environment, a Health Education syllabus was developed in the early 1980s. In this process it was clear that the Department of Education had taken heed of the lessons from the previous decade when extensive consultation had not been translated into action.

\section{The Development of a New Health Education Syllabus}

The development of the Health Education Syllabus (1985) drew much of its philosophy from the values education debates and initiatives of the 1970s. The syllabus development was challenging, for while there was broad agreement on much of the content, (topics such as "eating for health", "caring for the body", and "staying healthy") sexuality education was once again the source of great anxiety for the conservative groups. Extracts from letters written to the Department of Education state some of their concerns. A letter from a group calling itself "Integrity" to Roy Phillips (head of the Department of Education project team that developed the Health Education Syllabus) argued that the purpose of the syllabus revision was to, "increase the content of sexual activity" and claimed:

Ever since the Ross Report, there has been constant endeavour to remove the initiative from the Parents to the Classroom .... The evident reluctance of Educational authorities to acknowledge or accept the need for the Virtues to be explicit in the curriculum is nothing short of subversive. ("Integrity" to Phillips, March 23, 1983)

The letter concluded on a very distrustful note:

The Humanist, as already said, sanctions explicit sex education, while opposing explicit use of the Virtues. The conclusion is clear, that there is an intentional violation of our Traditional Christian morality within the Department. (1983)

The syllabus development team's summary of the first phase of the consultation process reflected a wider range of views. The summary notes that, despite the topic of sexuality education in primary schools ${ }^{6}$ being placed outside the consultation topics by the Minister,

... a very large number of groups made comments on sex education. The preliminary paper that preceded the consultations made clear that no change was intended in the provisions for sex education in primary schools. This meant that any suggestions regarding sex education were therefore limited to the context of secondary schools. A large number of groups asked for their opposition to this ruling to be recorded, seeing the need for home teaching to be supplemented by sound programmes at school, particularly in view of the lower age at which menarche now begins. (Department of Education, 1982, p. 6)

\section{A New Era?}

By the mid 1980s much had been achieved. The contentious nature of the debate remained, but the paralysis affecting national education initiatives was no longer an issue. This was due partly to a changing social and political environment and partly to the curriculum development framework used by the Department of Education to promote values education. The 1985 Health Education Syllabus was 
gazetted in 1990, providing formal recognition of the syllabus as the sole official curriculum document. A basis for sexuality education on a national scale was finally in place.

Consultation was legally embedded in the Health Education Syllabus. An Amendment to the 1964 Education Act required schools to consult with their communities on the content and implementation of health programmes. With reference to the 1985 Amendment, Helen Shaw, project director for the health education syllabus revision, noted:

It was the kind of commitment that we had made to all of the conservative groups (both those with a big $\mathrm{C}$ and a little $\mathrm{c}$ ) that schools would be required to consult parents. I saw that not so much as seeing parents as gatekeepers, but believing that my notions of health education could only flower in an environment where schools and parents were working together. (Personal communication, March 17, 1999)

She acknowledged the controversial nature of the sexuality education component of the new syllabus and the issue of authority: "whether young people should be taught to respect authority." When the Understanding Changes At Puberty resource was produced, the morally conservative groups became active again:

When we came to write the "Understanding Changes At Puberty" resource there was another great wave of antagonism and the Concerned Parents' Association took the paragraph on masturbation in the teaching resource and sort of blew it up into a newsletter and sent it all over the country saying, "look what the Department is doing next saying that masturbation is normal" so I would have heaps of questions about what did I think of masturbation. (Personal communication, March 17, 1999)

However, by 1986 , it seemed that a more liberal approach to sexuality education was gaining momentum. In retrospect, Shaw thought opposition was diminishing, and this is supported by comments from that time. A letter written to Shaw by Mike Andrew from Manning Intermediate (seconded to support teachers in the Christchurch area in Term One of 1986) reported:

A few weeks ago the Canterbury Federation of PTA's had an evening meeting on Keeping Ourselves Safe. ${ }^{7}$ The most vociferous opposition came from a group of parents I know well but it didn't seem to be quite so dogmatic as in the past so perhaps things are slowing down. (Andrew to Shaw, personal communication, April 1986)
Shaw suggested an evaluation of the Understanding Changes at Puberty resource undertaken by Gabrielle Maxwell from the University of Otago had an important effect:

It seemed to me a vindication of what we had set up when this piece of research was recorded [August 1986]. The kind of pressure we'd had from Concerned Parents' Association just absolutely vanished. It ("Understanding Changes At Puberty") had been taught in eighteen plus schools and "no, nothing had gone wrong". The kids hadn't all turned into hedonistic little louts but kids were able to talk.

The kids were more considerate of one another in the playground. All sorts of good things came out of it. It produced a completely different climate in the school. (Personal communication, March 17, 1999)

A letter written by a teacher at Rangiora High School to Shaw in 1987 indicated that things were apparently going well in secondary schools:

The work we've done with twenty staff using Life Skills and "Looking After Yourself" has been marvellous. We've just had all our parents in (third form 1987) over two nights and the twenty took turns being on deck to speak to parents, individually or in small groups about the programme and how we intend to use it. The school has taken on Peer Support from Australia (Rotary Support) and that also has very strong staff support. (Ussher to Shaw, personal communication, March 5, 1987)

\section{Not Enough Time in the Sun}

The gazetting of the Health Education Syllabus in 1990 required all primary and secondary schools to undertake implementation. According to Shaw, however, about one third of schools were not using the new syllabus. Shaw suggested a number of reasons for this including competition for teacher development funding. The major cause however, was to do with a new environment of school governance and administration:

EROcame in, everybody was focussed on different things, health got less and less publicity and promotion and the whole curriculum got neglected. Everyone was worried about administration and then gradually maths and English and single subject revisions came through. All of the in-service training was devoted to those. So it has been a tough time for health to have come through. It just didn't have enough time in the sun to make a difference. (Personal communication, March 17, 1999) 
Values Education Back on the Agenda Again

Values education was again given a national profile with the 1998 UNESCO Summit on values. After a decade when discussion about values education declined, Leader of the Opposition (former Prime Minister) Jenny Shipley suggested that schools should take a lead in reasserting social values.

Since 1998, there has been renewed interest in values education. This interest is seen in the emergence of new values education resources, educational conferences where values education has been a focus, such as the Quality Public Education Coalition (QPEC) Values in Education Conference held in 2000, and media attention, including a series of articles run by the New Zealand Herald in 2000.

The revival of interest in values education has been attended by controversy - values education remains a highly contested site, and issues that were contentious in the 1970s and 1980s have re-emerged.

\section{Sexuality Education - A Key Area of Learning}

The Health Education syllabus of 1985 was replaced in 1999 by Health and Physical Education in New Zealand. In this current document, sexuality education is designated a key area of learning and is required to be incorporated in programmes for students up to the end of year ten. The legislative provisions of the Education Act still apply. New legislation proposed by Trevor Mallard, Minister of Education in the current Labour-Alliance coalition government, aims to make sexuality education a compulsory part of the curriculum. (The right of parents to withdraw their children would remain.)

The perennial newsworthy nature of sexuality education was very evident when the new curriculum was released in 1999. The front page of the Dominion (February 12, 1999) featured a picture of Education Minister Nick Smith participating in a cooperative "grass ski" exercise at Karori Normal School in Wellington. Presumably the photo was meant to reflect the physical education component of the curriculum and the underpinning notions of cooperation and teamwork. Unfortunately the headline that accompanied the article said: "Sex-part names to be taught to primers." Another headline in the Sunday Times (February 8,1998 ) that appeared the day before the draft syllabus was published, proclaimed: "Let's talk about sex, baby."

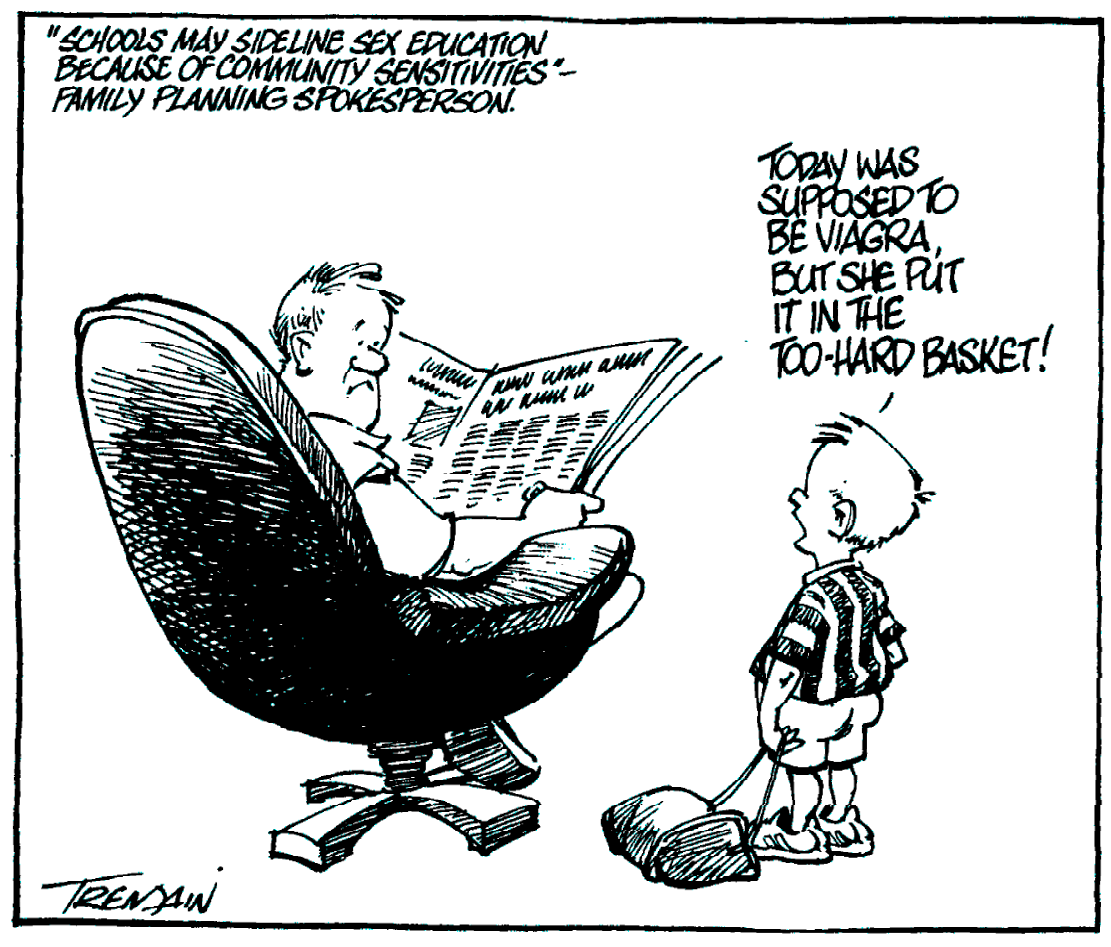

Teachers Need Support

The need for teacher preparation in values education was acknowledged in the 1970s and 1980s with a number of national courses being run. Professional development and pre-service preparation still remain important issues. Research undertaken by Alison Gray and Margery Renwick for the Ministry of Education and the Teacher Registration Board in 1998 showed that primary and secondary first year teachers were less confident about reinforcing the attitudes and values of the New Zealand Curriculum Framework (1993) in comparison with the essential skills. Most first year teachers failed to even answer these questions in the survey (Gray \& Renwick, 1998).

\section{What Values, Which Resources?}

The resourcing of moral education is another issue which has parallels with previous decades. One of the themes that emerged from the 
courses, conferences and reports of the 1970s and 1980s was the demand for values education to be resourced. The Department of Education initiated a number of developments in this area. Two of these developments, What Do You Think? (released over a number of years) written by David Elliot-Hogg and Stewart Christie, and More Than Talk (1978) written by Ivan Snook and Colin McGeorge, provide insights into Departmental processes and the way the Department responded to opposing viewpoints in a controversial curriculum area. In the case of both these publications, there was tension and ultimately neither publication was promoted by the Department. The end result was that schools were left to select their own resources with little guidance from the Department. Currently the Ministry of Education seems to be adopting a similar strategy - while values education publications from a variety of perspectives are on the increase, the Ministry is keeping a safe distance.

Values education today may not generate the passionate debates of the 1970s and 1980s but the issues, particularly those around sexuality education, continue to be controversial.

\section{Notes}

1. Prior to the 1990s the term "sex" education was the preferred term. Since then, "sexuality" education has been favoured. Sexuality education is used in this article for the sake of consistency.

2. "Moral education" is used to describe a particular area of "values" of which relationships and social norms are key elements. Moral education is inclusive of a range of education programmes that have operated in New Zealand schools since early last century. These programmes have included "character training", "family life education", "social education" "human development and relationship education" and "civics". During the 1970s and early 1980s, "values education" gradually replaced the term "moral education".

3. Patricia Bartlett was founder of the Society for the Protection of Community Standards and a well known campaigner on moral issues through the 1970s and 1980s.

4. In L. W. Gandar's introduction to Education, Number 4 (1978) (a special issue on the Johnson Report) he noted: "The Johnson Committee studied reports from earlier committees on education and its Report should be considered along with reports such as Towards Partnership.

5. The material referred to was in set 74 , No. 2, published by the New Zealand Council for Educational Research. The first edition of set was published in May of 1974. Copies were distributed direct from NZCER to all state and private schools, teachers' colleges, technical institutes and universities. Additional copies were made available to inspectors and Department of Education staff.

6. Both primary and post primary schools were subject to the regulations of the 1964 Education Act as it pertained to curriculum content, but primary schools were also bound by the 1945 Health Education syllabus which put explicit limits on sexuality education.

7. Keeping Ourselves Safe was jointly developed by the Education Department and the New Zealand Police Department in the mid 1980s. The resource was a response to the issue of sexual abuse that was gaining attention around the time the Health Education syllabus was being developed.

\section{References}

Concerned Parents' Association. (1974). Papers held on restricted file. Wellington: New Zealand Family Planning Association, Alexander Turnbull Library.

Department of Education. (1969). Health: Suggestions for health education in primary schools. Wellington: Department of Education.

Department of Education. (1973). Human development and relationships in the school curriculum. Wellington: Department of Education.

Department of Education. (1977). Growing, sharing, learning. The report of the Committee on Health and Social Education. Wellington: Department of Education.

Department of Education. (1982). Health education in primary and secondary schools: Syllabus revision. Report on consultations, draft syllabus. Wellington: Department of Education.

Department of Education. (1987). Understanding changes at puberty. Health Education trial unit for designated schools. Wellington: Department of Education.

Dominion (1999, February 12), p. 1.

Elliot-Hogg, C., \& ChristieS. (1965-1977). What do you think? An audiovisual programme. Tauranga: Council of Organisations for Moral Education.

Else, A., \& Noonan, R. (1993). Unfinished business. In S. Kedgely \& M. Varnham (Eds.), Heading nowhere in a navy blue suit. Wellington: Daphne Brasell Associates. 
Gray, A., \& Renwick, M. (1998). A study into the effectiveness of teacher education programmes. A report prepared for the Ministry of Education and the Teacher Registration Board. Wellington: Research Division, Ministry of Education.

Ministry of Education. (1999). Health and physical education in the New Zealand curriculum. Wellington: Ministry of Education.

New Zealand Herald. (n.d.) Extract found in Department of Education files, ABEP W4262, 34/1/53, Pt 1.

New Zealand Herald. (n.d.) Article found in Department of Education files, ABEP W4262, 34/2/17, Pt 2.

New Zealand Truth. (1978, September 9).

Snook, I., \& McGeorge, C. (1978). More than talk: Moral education in New Zealand. Wellington: Department of Education.

Stirling, Pamela (1998, April 18). Sex + school $=$ sin. New Zealand Listener, pp. 30-31.

Sunday Times (1998, February 8).

Tremain, Garrick. (1999). The best of 99, Garrick Tremain cartoons, Vol. 10. (Cartoon used with the author's permission.)

\section{The author}

Kama Weir is a lecturer in Health Education at Massey University College of Education. Prior to her appointment to Massey in 1996 she was a senior teacher and the health education co-ordinator at Central Normal School in Palmerston North. 